\title{
Food Preferences of Deer in Relation to Winter Fodder Including Woody Plants
}

\author{
Eleonora SZUKIEL
}

Szukiel E., 1981: Food preferences of deer in relation to winter fodder including woody plants. Acta theriol., 26, 19: 319-330 [With 2 Tables \& 3 Figs.].

Different versions of silage in which $10-30 \%$ was formed by twigs of trees from current growth or $10-40 \%$ pine bark free of cork were drawn up. These two kinds of food and two others: dried shoots of woody plants and fresh pine bark, were used during the period from 1976-1979 for supplementary winter fodder for red deer in an enclosure, and for roe-deer, fallow deer and red deer in 4 open biotopes in the lowland forests of Poland. Almost $100 \%$ of the twigs of trees and shrubs of 17 deciduous species and pine bark in such silage, were consumed by the deer. The twigs of different species were equally readily consumed in silage, including those species which are avoided or not readily consumed in the fresh or dried form, e.g., Frangula alnus and Symphorycarpus album. Dried twigs were eaten less readily, about $19.9-53.5 \%$ of total mass, while the thicker parts of twigs were not eaten at all, even under conditions of extreme hunger in the enclosure. Dry branches were eaten selectively, Populus tremula and Sorbus aucuparia being most favoured. Red deer readily stripped bark from felled trees. One pine (about 100 years old) supplied them with as much fresh bark (e.g., $13.1 \mathrm{~kg}$ ) as they strip from 657 to 2628 growing pines (about 8 years old), causing great damage by stripping in this way. It was found that silage containing twigs or bark, and also bark on felled pines, form food readily and completely consumed in winter by deer: there may be considerable benefit from supplying them with such fodder and may result in, inter alia, reducing the considerable damage done by browsing and bark-stripping. Poland].

[Instytut Badawczy Leśnictwa, Wery Kostrzewy 3, 02-362 Warszawa,

\section{INTRODUCTION}

Deer (Cervidae) occurring numerously in the cultivated regions of densely inhabited Europe have been obliged to alter their diet from herb layer plants and grasses to woody plants and agricultural crops, which causes economic losses and disturbance in forest ecosystems (Gattinger, 1980; Hofmann, 1980; Szukiel, 1980). The proportion of browse in the diet of deer (i.e., leaves, twigs, young shoots and bark of woody plants) increases in winter to $90 \%$ (Dzięciołowski, Kossak, Borowski, Morow, 1975). Consumption of woody plants has thus now become an established food habit of these herbivorous animals. They most often prefer the tree species forming tall forests, such as Pinus silvestris, Abies alba, Picea excelsior, Larix spp., Fagus silvatica, Fraxinus excelsior, Acer platanoides and Quercus spp. (Dzięciołowski et al., 1975; Bobek et al., 1979). The damage done by browsing and bark-stripping from trees 
hinders forest renewal and has a harmful effect on its species composition.

The second kind of food consumed by deer has now become agricultural crops, e.g., potatoes, beet or maize grains; they are eaten from spring to autumn in cultivated fields and in winter on supplementary feeding sites in forests. Consumption of such food not only causes considerable losses in agriculture, but also has an unfavourable effect on the digestive system of wild ruminants, on their feeding habits and, as an indirect results, is the cause of increased damage in forests.

The results of studies on the physiology of the food habits of wild and domesticated ruminants indicate the need for a new direction in the search for enrichment of the winter food supply of deer, in order to enable them to survive the winter and also to limit browsing and bark-stripping of cultivated trees (Ruszczyc, 1973; Missbach, 1975; Onderscheka, 1976; Podkówka, 1978).

The purpose of these studies was to examine and determine the suitability of several kinds of winter food, including woody plants, to determine the food preferences of deer in relation to such food and to estimate the degree to which the deer make use of it in their winter diet.

The hypothesis was taken as a starting point that supplying deer during winter with fodder, in suitable amounts and form, enriched with leaves, twigs and bark of trees and shrubs of the species most often consumed by them during the period when they are available in the biotope, would be in accordance with the animals' physiological and food requirements, and would consequently exert a favourable effect on their condition and health and limit browsing and bark-stripping.

The paper presents the results of the first stage of studies. They relate to the suitability of fodder containing woody plants. During the second stage examination will be made of the effect of supplementary feeding wild animals with such fodder on extent of browsing and barkstripping.

\section{MATERIAL AND METHODS}

Four kinds of experimental food were prepared, containing woody plants: (1) leaf fodder, that is, dried twigs of deciduous species of trees and bushes, (2) silage including woody twigs of the same deciduous species, (3) silage including pine bark, (4) fresh pine bark in the form of felled trees for bark-stripping.

1 Choice of species of twigs for the experiments on different stations and in different years depended primarily on their availability in a given biotope. 
Leaf fodder and silage were prepared by obtaining twigs from annual growth during the peak period of the growing season. Dried young twigs and shoots, together with leaves, were prepared in bundles composed of one or more species. On one site a total of 230 bundles composed of 5-9 species of twigs were prepared: the average weight of the fresh mass in a bundle was about $1 \mathrm{~kg}$.

Fresh pine bark was laid out for the animals in the form of felled trees for bark-stripping in December before the start of the feeding experiments.

Silage containing twigs and shoots was made in summer during the peak growth season, and silage containing bark - in autumn during the harvesting period of maize and root crops. The basic raw materials of silage were: beet leaves, cabbage, the green parts of maize, grasses, papilionaceous plants etc. (Ruszczyc, 1973; Podkówka, 1978). Twigs of the same species from which the leaf mixture was prepared (Fig. 1), but in the fresh state into $5 \mathrm{~cm}$ lengths, were added in amounts of $10-30 \%$ to the prepared silages.

The experiments were carried out on four stations at a distance from each other, in open shooting areas in which three species of Cervidae lived. The forest administration districts of: Iława (Olsztyn Hunting Union Region), Janów Lubelski and Józefów (Lublin Hunting Union Region) are inhabited by roe-deer (Capreolus capreolus Linnaeus, 1758) and red deer (Cervus elaphus Linnaeus, 1758), Kobiór (Katowice H.U.R.) - roe-deer, fallow deer (Dama dama, Linnaeus, 1758) and red deer. The same experiments were carried out simultaneously in an enclosure at Ilawa containing 3 red deer.

The experiments using silage were repeated during three successive winter seasons from 1976-1979 in 3-4 stations, and using leaf mixture and fresh bark from $1976-1979$ on $2-3$ stations.

Experiments with supplementary feeding were carried out during the period from December to March simultaneously on 2-4 stations, laying out at the same time weighed portions of leaf mixture and silage. Fresh portions of silage from $5-50 \mathrm{~kg}$, and from 5 to 15 bundles of leaf mixture, were laid out daily or every few days. Experiments on one station in each winter season lasted from 7 to 53 days, while observations in the enclosure were made daily for several hours, and in the open shooting areas - daily or every few days. Modifications of the details of these methods were made on different stations and in different seasons in order to obtain a greater variety of observations on the way in which deer feed depending on the kind of fodder, the way it was laid out and also depending on the prevailing weather conditions (temperature and precipitation) during the supplementary feeding period.

In all during the period of 3 study seasons 1066 bundles of leaf mixture prepared from 17 species of trees and shrubs, and 28 tons of silage prepared in accordance with 19 different recipes, were laid out, and also 50 trees for bark-stripping.

The amount of bark stripped by red deer from the felled trees (in 3 variants of bark-stripping) was determined in spring by measuring the stripped area and weighing samples of bark taken from the unstripped surface. The amount of bark stripped by red deer on pines growing in young tree plantations (with 4 variants of bark-stripping) was defined in a similar way. Using these data, comparison was made for 12 variants of the supply of bark for stripping by red deer on a felled pine (tree from 60-100 years old) and on a growing pine (from 8-12 years old).

Acta theriol., 4 


\section{STUDY AREA}

Detailed phytosociological descriptions of the above study areas and the state of their wildlife management are to be found in earlier papers (including Dzięciołowski, 1968; Szukiel, 1979). These are lowland forests with average food conditions for deer, with a predominance of coniferous stands: fresh coniferous forest at Józefów and Janów Lubelski, fresh mixed coniferous forest at Iława and moist mixed coniferous forest at Kobiór.

The density of red deer in these areas did not exceed 20 animals per 1000 ha wooded area. During the study period there were from 2-4 red deer in an area of 18 ha in size in the enclosure at Ilawa.

On all stations deer were provided with similar supplementary feeding during the winter, chiefly bulk dry fodder (hav, mixture of papilionaceous plants) and root crops (potatoes and beets) and occasionally concentrated food (maize grain, oats) or succulent bulk fodder (kale, artichoke).

The areas referred to have for 20 years (Janów Lubelski for 5 years) been areas for studying damage and protection methods (Szukiel, 1973, 1979 a, b). Damage done by deer in crops and young tree plantations on all four stations: the greatest damage due to browsing and bark-stripping of trees at Kobiór and due to bark-stripping at Józefów, while relatively the least damage is done at Janów Lubelski by browsing and bark-stripping.

\section{RESULTS AND DISCUSSION}

Leaf mixture has been a fodder in fairly general use for over sixty years for winter supplementary feeding of red deer and roe-deer in the forests of Central Europe. It is also known that dried twigs and shoots from the current year's growth are rarely completely consumed by the deer. The experiments made by the author supplied preliminary information as to the preference of deer for the dried twigs and shoots of 17 species of trees and bushes, and the degree to which they were used (in \% of biomass) by these animals.

Both the red deer in the enclosure and roe-deer, fallow deer and red deer in open shooting areas consumed the leaf mixture of different species of tree and shrub selectively. The food preferences of deer in relation to the leaf mixture varied in respect of the same woody plant species (Fig. 1), depending on a large number of factors. It depended, inter alia, on the quality of the biotope and probably also on the local food habits of the animals. In biotopes where food conditions were relatively good (in open shooting areas at Iława and Janów Lubelski) the leaf mixture was a food of little attraction to deer: either it was not consumed at all (at Iława) or only small amounts (at Janów Lubelski, Fig. 1C). In biotopes where food conditions were poorer (in the open shooting area at Kobiór and in the enclosure at Ilawa) the leaf mixture was far more readily eaten, probably on account of the limited availa- 
bility, or lack, of different food. Observations made in the enclosure show that red deer preferred standard food (hay, beets and carrots): it was only when such food was limited or absent that they began to eat the leaf mixture. Both red deer in the enclosure, and roe-deer, fallow deer and red deer in the open shooting area, even when the availability of other food was limited (Kobiór), or absent (Iłiwa), unwillingly consumed the twigs of certain woody plants. In the enclosire the deer did not readily eat Tilia cordata, Corylus avellana, Frangula alnus or Symphorycarpus album (Fig. 1A), and in the open shooting area Betula verrucosa and Quercus robur (Fig. 1D).

Consumption by deer of dried twigs of species, usually preferred by them in the fresh state, such as oak, Acer platanoides, Salix caprea varied from station to station and in seasons. For instance Quercus robur, fairly readily eaten in the enclosure at Ilawa (Fig. 1A, B) and in the open area at Janów Lubelski (Fig. 1C), was not attractive to the animals at Kobiór in the form of leaf mixture, although fresh twigs are readily eaten there (Fig. 1D). Salix caprea came fifth in respect of its at-

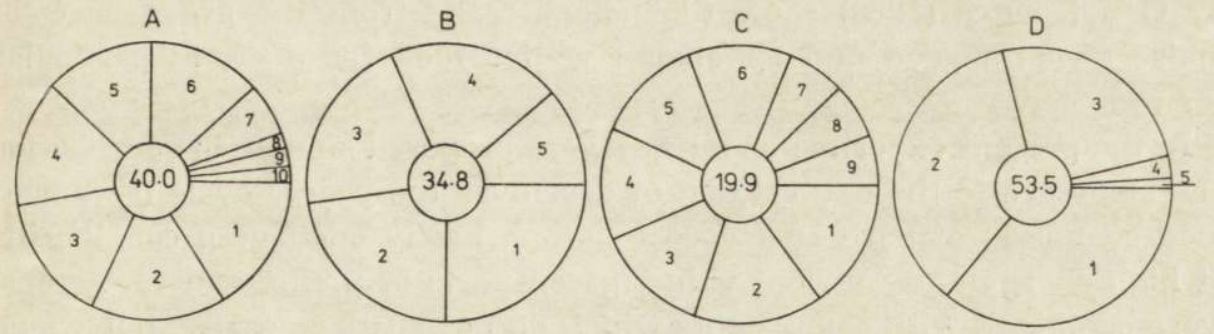

Fig. 1. Food prefere nces of deer in relation to different variants of leaf mixture, examined in four different regions of Poland.

A - leaf mixture from 10 species of trees and bushes, consumed by red deer in the enclosure at Ilawa. Winter 1976/77. Order of preference obtained: 1. Acer platanoides $16 \%$; 2. Acer pseudoplatanus $16 \%$; 3. Populus tremula $15 \%$; 4. Quercus robur $15 \%$; 5. Salix caprea $13 \%$; 6. Sambucus nigra $13 \%$; 7. Tilia cordata $6 \%$; 8. Corylus avellana $2 \%$; 9. Frangula alnus $2 \%$; 10. Symphorycarpus album $2 \%$. B - leaf mixture from 5 species of trees consumed by red deer in the enclosure at Ilawa, winter 1977/78. Order of preference obtained: 1. Populus tremula $25 \%$; 2. Sorbus aucuparia $23 \%$; 3. Quercus robur $21 \%$; 4. Acer platanoides $20 \%$; 5 . Quercus rubra $1 . \%$.

C - leaf mixture from 9 species of trees and bushes, consumed by red deer and roe-deer in the shooting area at Janów Lubelski, during the 1976/1977 season. Order of preference obtained: 1. Sambucus nigra $15 \% ; 2$. Sorbus aucuparia $15 \%$; 3. Pirus spp. $14 \%$; 4. Quercus robur $14 \%$; 5. Fagús silvatica $12 \%$; 6. Populus tremula $12 \%$; 7. Tilia cordata $7 \%$; 8. Ribes spp. $6 \%$; 9 . Salix caprea $5 \%$.

D - leaf mixture of 5 species of trees, consumed by red deer, fallow deer and roe-deer in the open shooting area at Kobiór during the season 1976/77. Order of preference obtained: 1 . Populus tremula $36 \% ; 2$. Sorbus aucuparia $35 \%$; 3. Aesculus hippocastanum $25 \%$; 4. Quercus robur $2.4 \%$; 5 . Betula verrucosa $1.6 \%$. Number in the middle of the circle shows mean percentage (dry wt.) of leaf mixture eaten. 
tractiveness to deer in the middle of the order of preference) according to results of experiments in the enclosure (Fig. 1A), but only ninth (last place) according to the results of experiments from the open shooting area at Kobiór. Under all conditions the species most preferred on three stations were: Populus tremula and Sorbus aucuparia.

Leaf mixture was not fully used as winter fodder, as the deer consumed mostly the leaves and tips of the twigs, leaving the thicker, more woody parts of twigs from the current year's growth. The percentage of biomass of the leaf mixture consumed was on an average 19.9 in the station with better food conditions (Fig. 1C) and 34.8, 40.0 and 53.5 under conditnons of limited availability of other food (Fig. 1A, B, D).

Attempts at using twigs of trees and bushes, shrubs and plants of the forest herb layer for preparing silage for wild animals, instead of the leaf-mixture, have been undertaken previously by other authors (Bubenik, 1960; Zdanowicz, 1970), but good silage was not obtained by using the above groups of plants as the basis. Later on other authors tried using agricultural silage for winter supplementary feeding of deer (inter alia Missbach, 1975; Onderscheka, 1976). The most recent studies by Onderscheka (1980) show that silage made from the green parts of maize forms a good and appetising winter food for deer, in particular for red deer.

In the present experiments silages were prepared similar in composition and structure to the natural diet of deer over the yearly cycle (succulent food composed of herb and woody plants). Easily ensilaging components of high energy and nutrient value (green parts of plants and root crops) were combined with components which do not ensilage easily, but which are included in the composition of the natural, particularly the winter, diet of deer (twigs and bark of trees and bushes).

By using succulent and easily ensilaging raw materials, a successful silage was obtained, with the inclusion of twigs or of tree bark. The best raw base for ensilaging twigs and bark of woody plants proved to be the leaves of beet or cabbage and the green parts of maize. Among the 19 recipes prepared and made up in 3 seasons, silage composed of woody twigs, beet leaves and the green parts of maize, in proportions of $1: 1: 1$, and silage of pine bark and cabbage leaves in proportions of $3: 7$, proved to be the most successful and appetising silages.

Almost $100 \%$ of the woody twigs in the silages were eaten both by red deer in the enclosure and red deer and roe-deer in the open shooting areas. As soon as the animals became accustomed to this new form of food, i.e., silage, they consumed it completely in the compositions prepared. Ensilaged twigs were completely consumed, regardless of the species: probably the specific smell and taste of the ensilaged products 
and the silage juice reduced or eliminated differences in the degree of the attractiveness to the deer of different species of plants. Twigs of trees and bushes which are not attractive to deer were also used in silage, e.g., twigs of Betula sp. and Frangula alnus (Fig. 1A, D).

Silages containing pine bark were also readily eaten by deer. The long, uncut strips of succulent bark in silage with beet leaves, cabbage, green parts of maize or grasses were readily consumed, both from the whole portion of silage and when also selected from it and laid out separately.

Observations of feeding deer in the enclosure also show that consumption (chewing) of woody twigs in the silage took them far longer than consumption of the other components in the form of herb layer plants. For instance, during the course of one observation period, a hind consumed $2.5 \mathrm{~kg}$ of silage containing twigs within one and a half hour. Chewing up bark strips similarly lengthens feeding time. Lengthening of feeding time and chewing is favourable to the process of digestion and also tends to limit the damage done by browsing and bark-stripping (Szukiel, 1980).

The period required for the deer in open shoots to become accustomed to new food with a special strong smell, such as is characteristic of silage, varied in different study stations. If the silage had been laid out for the first time in a given biotope, the deer did not approach it for several weeks, or even - in biotopes with better food conditions for the whole of the first study season.

A distinct relation between consumption of silage and ambient temperature was observed. In open areas the deer began eating silage when temperature dropped below $0^{\circ} \mathrm{C}$, and ceased approaching it as temperature rose and settled above freezing point. During the study period from 1976-1979 deer consumed silage from approximately the beginning of January to mid-March. Deer consumed the greatest amounts of silage in the third, that is, the last, study season, in both the enclosure and in the open areas. This was due primarily to two factors: the animals' habituation during the two previous seasons to the new form of food and the lack of natural food, particularly succulent food, during an exceptionally severe winter. In this season from November to March deviation from normal air temperature was on an average for the study stations $-2.2{ }^{\circ} \mathrm{C}$, and total precipitation $124.1 \%$ of the normal. During this period there were 60 days with minimum temperature below $0^{\circ} \mathrm{C}$ at ground level and 60 days with snow cover deeper than $5 \mathrm{~cm}$.

During the three seasons when experimental fodder containing woody parts was laid out there was no bark-stripping of the trees near the feeding place on any of the 4 study stations. This justifies the assumption 
that when fodders containing woody components are consumed by deer this may reduce bark-stripping from trees. This forms a phenomenon commonly observed in forest shoots in Central Europe, in places near sites on which standard fodder, such as hay or root crops, is laid out.

In experiments with laying out felled trees for the deer to strip bark from them the degree of attractiveness, way and extent of the use made of this kind of food by red deer were determined (locally also by fallow deer - roe-deer do not strip bark from trees). The experiments applied to the common pine, which is a species predominating in the forests of Central Europe (and also on the 4 study stations).

The results of these experiments and practical observations show that red deer prefer eating bark from felled trees to growing trees, particularly from 9-12-year old, still slender pine trunks. Most often at

Table 1

Percentage of bark stripped by red deer from felled pines depending on the height at which they were set above ground level.

\begin{tabular}{|c|c|c|c|c|c|}
\hline \multirow{2}{*}{$\begin{array}{c}\text { No. of } \\
\text { tree }\end{array}$} & \multirow{2}{*}{$\begin{array}{l}\text { Diameter of } \\
\text { thicker end, } \\
\mathrm{cm}\end{array}$} & \multirow{2}{*}{$\begin{array}{l}\text { Height of } \\
\text { tree from } \\
\text { ground, cm }\end{array}$} & \multirow{2}{*}{$\begin{array}{l}\text { Circumference at } \\
\text { place of measurement } \\
\text { of bark-stripping, cm }\end{array}$} & \multicolumn{2}{|c|}{$\begin{array}{l}\text { Extent of bark-stripping } \\
\text { on circumference }\end{array}$} \\
\hline & & & & $\mathrm{cm}$ & $\begin{array}{c}\% \text { of } \\
\text { circumference }\end{array}$ \\
\hline 1 & 15 & 0 & 52 & 23 & 44.2 \\
\hline 2 & 20 & 5 & 73 & 40 & 54.8 \\
\hline 3 & 18 & 5 & 60 & 40 & 66.7 \\
\hline 4 & 16 & 15 & 55 & 30 & 54.5 \\
\hline 5 & 12 & 15 & 45 & 25 & 55.5 \\
\hline 6 & 23 & 15 & 70 & 55 & 79.4 \\
\hline 7 & 11 & 35 & 40 & 24 & 60.0 \\
\hline 8 & 18 & 35 & 60 & 37 & 51.7 \\
\hline 9 & 15 & 55 & 52 & 39 & 75.0 \\
\hline
\end{tabular}

this age the pine has soft bark, attractive to red deer and within their reach, usually on the third annual growth. Probably the slenderness of tree trunks at this age, and the natural habit of wild animals to consume food from the ground, cause red deer to prefer stripping bark from a fallen rather than from a standing tree.

The extent of the stripped surface of trees depends primarily on their morphological characteristics. Tall trunks with smooth bark were stripped almost completely over the whole of the accessible surface. Red deer were found to strip more thoroughly in biotopes with poorer food conditions.

The extent of the surface accessible to bark-stripping depended on the way in which the felled tree was placed. Logs lying on the ground or in the snow were usually stripped over an area of about $50 \%$ of the circumference. When placed at a certain height from the ground, from 
5 to $50 \mathrm{~cm}$, the red deer were enabled to strip a far greater area, even up to $79.4 \%$ of the log's circumference. Table 1 gives as an example the results measurements of stripped surface on several trees placed at different heights from the ground. A plan and dimensions of the model tree used for further calculations are given in Fig. 2. The amount of stripped bark on it was calculated for three variants A, B and C (Fig. 3 ), the average weight of fresh pine bark per $1 \mathrm{dcm}^{2}$ of felled tree having been determined beforehand. This weight was $15.5 \mathrm{~kg}$, while

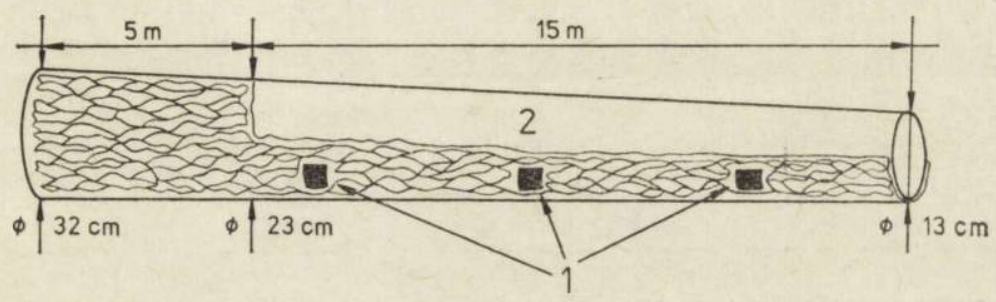

Fig. 2. Diagram of model tree.

1 - place from which bark samples were taken, measuring $10 \times 10 \mathrm{~cm}$, mean weight 15,5 g. 2 - bark stripped over half circumference of tree.
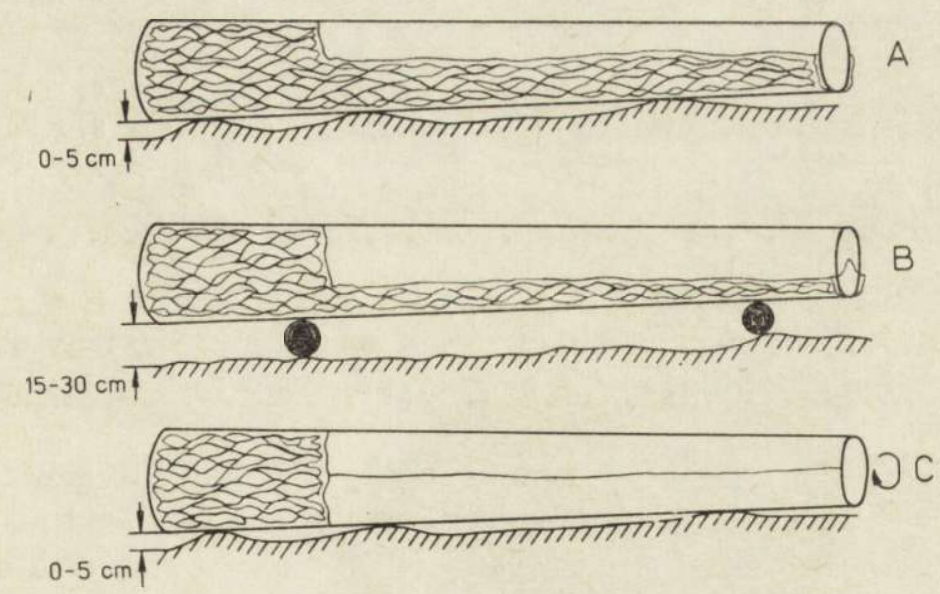

Fig.. 3. Extent of bark-stripping from pine depending on height from ground at which placed.

A - lying directly on ground, bark stripped from half circumference

B - on supports. $15-30 \mathrm{~cm}$, bark stripped from $2 / 3$ of circumference of trunk C - lying directly on ground, trunk turned over halfway through winter - bark stripped over whole circumference of trunk. 
the average weight of fresh bark obtained from one space between whorls of a $7-8$ year old pine was from 5 to $20 \mathrm{~g}$, depending on the variant of bark-stripping.

Results from comparison in 12 variants of the amount of bark on the model tree and on standing trees are given in-Table 2. The studies showed that fallen trees supply red deer with a far greater amount of bark for stripping than standing trees. One pine felled for bark-stripping supplied red deer with approximately 5 to $13 \mathrm{~kg}$ of fresh bark, which is equivalent to the amount stripped by these animals during winter from approx. 650 to 1300 pines over the whole area between whorls (lethal damage), or from approx. 1300 to 2600 pines stripped over an area about half of that between whorls. Other species of trees, also

Table 2

Comparison of the amount of bark stripped on a 100-year old felled pine and on $8-10$ year-old standing pines.

\begin{tabular}{|c|c|c|c|}
\hline Items & A & B & $\mathrm{C}$ \\
\hline \multicolumn{4}{|c|}{ Bark biomass without cork on a model pine } \\
\hline Area of bark stripped, $\mathrm{dcm}^{2}$ & 423.9 & 565.2 & 847.8 \\
\hline Mass of bark stripped, $\mathrm{g}$ & 6570.5 & 8760.6 & 13140.9 \\
\hline \multicolumn{4}{|c|}{ Equivalent amount of barked trees in young tree plantations } \\
\hline \multicolumn{4}{|l|}{ Winter barking, $\mathrm{a}=10 \mathrm{~g}^{1}$} \\
\hline Bark stripped from whole surface between whorls & 657 & 876 & 1314 \\
\hline $\begin{array}{l}\text { Rark stripped from half surface between whorls } \\
\text { Summer barking, } \mathrm{b}=20 \mathrm{~g}^{1}\end{array}$ & 1314 & 1752 & 2628 \\
\hline Bark stripped from whole surface between whorls & 329 & 438 & 657 \\
\hline Bark stripped from half surface between whorls & 657 & 876 & 1314 \\
\hline
\end{tabular}

1 Weight of bark from area stripped by red deer between whorls of pine is $10 \mathrm{~g}$ in winter, and $20 \mathrm{~g}$ in summer (barking to ligneous layer)

readily stripped by deer, such as aspen, spruce and fir, may supply far more bark for stripping, as the area occupied by cork is far smaller on these trees.

To sum up the results of studies on the suitability of new forms of winter food it must be said that deer readily consume food in the form of fresh bark from felled trees, and silages containing tree and bush twigs, or tree bark. They less readily consume dried shoots of woody plants and in addition do not make full use of them. Shoots and bark of woody plants as silage, and fresh bark from felled trees, supply deer with natural food components in winter, in the form of succulent food.

The objections made by some authors that supplying deer with such food has imprinted a new food habit would not appear justified. Con- 
sumption of plants occuring in biotopes and eaten by wild animals, including leaves, shoots and bark of wody plants, is a more natural food habit of such wild herbivores than eating potatoes, beet, maize and other kinds of agricultural fodder. Consumption by deer of only mass dry fodder such as hay, or only succulent fodder, such as beets, or only concentrated fodder such as cereal grain, has an unfavourable effect on the digestion, health and development condition of these ruminants. Deer supplement this incorrect winter diet by browsing on shoots of young planted trees and stripping tree bark (Onderscheka, 1980; Szukiel, 1980).

There are thus grounds for assuming that enriching the biotope of deer in winter with food containing woody elements contributes to reduction of the damage these animals do by browsing on plant shoots in plantations and stripping bark from trees in thickets and older stands.

\section{REFERENCES}

1. Bobek B., Perzanowski K., Siwanowicz J. \& Zieliński J., 1979: Deer pressure on forage in a deciduous forest. Oikos, 32: 373-380.

2. Bubenik A., 1964: Retezove krmeni $\mathrm{v}$ teori a praxi. Myslivost, 7-8: 106-107.

3. Dzięciołowski R., 1968: Pokarm jelenia europejskiego (Cervus elaphus L.) w cyklu rocznym. Prace IBL, 365, 32: 303-314.

4. Dzięciołowski R., Kossak S., Borowski S. \& Morow K., 1975: Diet of big herbivore mammals. Pol. ecol., Stud., 2: 33-50.

5. Gattinger G., 1980: Verbesserung des Lebensraumes Freilebender Wildtiere minderung des Wildschadens. Proc. Symp. C.I.C., Salzburg.

6. Hofmann R. R., 1980: Wildbiologische Erkenntnisse, ein Hilfsmittel zur Minderung der Wildschäden. Proc. Symp. C.I.C., Salzburg.

7. Missbach K., 1975: Beziehungen zwischen Winterfütterung und Schalschaden des Rotwildes (Cervus elaphus L.). Beitr. Jagd-u. Wildforsch., 10: 26-48.

8. Onderscheka K., 1976: Beitrag zum Thema der Winterfutterung des Rotund Rehwildes. Osterreichs Weidwerk, 11: 1-4.

9. Onderscheka K., 1977: Huswahl, Konservierung und Lagerung von Rot-und Rotwildfutter. Osterreisch Weidwerk, 4: 5-20.

10. Onderscheka K., 1980: Untersuchungen der Wechselwirkung zwischen Rotwildpopulation und umwelt unter besonderer Berucksichtigung der Ursachen der Wildschaden. Proc. Symp. C.I.C., Salzburg.

11. Podkówka W., 1978: Nowoczesne metody kiszenia pasz. PWRiL: 1-378. Warszawa.

12. Ruszczyc Z., 1973: Żywienie zwierząt i paszoznawstwo. PWRiL: 1-475. Warszawa.

13. Szukiel E., 1973: Zastosowanie smoly weglowej do ochrony upraw sosnowych przed zwierzyną płowa. Prace IBL, 438: $1-74$.

14. Szukiel E., 1979a: Szkody w lasach Polski na tle zagęszczenia jeleniowatych. Prace IBL, 546: 135-159. 
15. Szukiel E., 1979b: Chemiczne metody ochrony młodników sosny zwyczajnej (Pinus silvestris L.) przed spałowaniem przez jelenia (Cervus elaphus L.). Prace IBL, 575: 1-73.

16. Szukiel E., 1980: Studies on reducing deer damage in Poland. Proc. Symp. C.I.C., Salzburg.

17. Zdanowicz Z., 1970: Kiszonki w gospodarstwie lowieckim. PWRiL: 1-91. Warszawa.

Accepted, March 17, 1981.

Eleonora SZUKIEL

\section{WYBIORCZOSC JELENIOWATYCH WOBEC ZIMOWEJ KARMY Z UDZIAEEM ROSLIN DRZEWIASTYCH}

\section{Streszczenie}

Opracowano udatne kiszonki zawierające $10-30 \%$ pędów drzewiastych $\mathrm{z}$ bieżących przyrostów lub $10-40 \%$ kory sosny bez martwicy korkowej. Te dwie formy karmy oraz dwie inne: wysuszone pędy drzewiaste i. świeżą korę sosny zastosowano w latach 1976-1979 do zimowego dokarmiania jeleni (Cervus elaphus L.) w zagrodzie oraz sarn (Capreolus capreolus L.), danieli (Dama dama L.) i jeleni w 4 biotopach otwartych w lasach nizinnych Polski. Pędy drzew i krzewów 17 gatunków liściastych oraz kora sosny w kiszonkach byly zjadane przez jeleniowate prawie w $100 \%$. Pędy różnych gatunków byly zjadane w kiszonkach jednakowo, lącznie z tymi, które są omijane lub niechętnie zjadane w postaci świeżej lub wysuszonej, np. kruszyna (Frangula alnus) i śnieguliczka (Symphorycarpus album) (Rys. 1 A). Wysuszone pędy tych samych co w kiszonkach 17 gatunków liściastych były zjadane mniej chętnie i zaledwie w ilości $19,9-53,5 \%$ wagowych; nie były zjadane grubsze odcinki pędów, nawet $w$ warunkach głodowych $w$ zagrodzie. Pędy wysuszone były zjadane wybiórczo (Ryc. 1, A-D), przy czym najchętniej jeleniowate zjadały osikę (Populus tremula) i jarzębinę (Sorbus aucuparia). Jelenie chętnie spałowały korę na ściętych drzewach (Tabela 1). Jedna sosna (ok. 100-letnia) dostarczała im tyle świeżej kory (np. $13,1 \mathrm{~kg}$ ), ile pobierają z 657 do 2628 sosen rosnących (ok. 8-letnich), wyrządzając duże szkody wskutek spałowania (Tabela 2, Ryc. 2, 3). Stwierdzono, że kiszonki z pędami lub korą oraz kora na ściętych sosnach stanowią karmę chętnie i w pełni zjadaną przez jeleniowate. Dokarmianie zimą jeleniowatych taką karmą jest bardziej ekonomiczne niż stosowanymi dotąd w Europie paszami rolniczymi (np. sianem, okopowymi, ziarnem zbóż) oraz może być korzystniejsze dla metabolizmu tych dzikich przeżuwaczy i przyczynić się m.in. do mniejszania szkód wyrządzanych przez nie zgryzaniem i spałowaniem drzew. 